\title{
Philopatry and natal dispersal of Montagu's harriers (Circus pygargus) breeding in Spain: a review of existing data.
}

Ruben Limiñana ${ }^{1,2^{*}}$, Jesús T. García ${ }^{1}$, Juan Miguel González ${ }^{3}$, Álvaro Guerrero ${ }^{4}$, Jesús Lavedán ${ }^{5}$, José Damián Moreno ${ }^{5}$, Antonio Román-Muñoz ${ }^{3}$, Luis E. Palomares ${ }^{6}$, Antonio Pinilla ${ }^{4}$, Gregorio Ros ${ }^{7}$, Carlos Serrano ${ }^{8}$, Martín Surroca ${ }^{9}$, Jesús Tena ${ }^{10}$ \& Beatriz Arroyo ${ }^{1}$

${ }^{1}$ Instituto de Investigación en Recursos Cinegéticos (IREC). CSIC-UCLM-JCCM. Ronda de Toledo, s/n. Ciudad Real E-13005, Spain.

${ }^{2}$ Estación Biológica Terra Natura. Instituto Universitario de Investigación CIBIO. Universidad de Alicante. Apdo. 99. Alicante E-03080, Spain.

${ }^{3}$ Fundación MIGRES. N-340, Km. 96.2. Huerta Grande, Pelayo E-11390 Algeciras, Cádiz, Spain.

${ }^{4}$ AMUS. Apdo. Correos 6. E-06220 Villafranca de los Barros, Badajoz, Spain.

${ }^{5}$ ANSAR Valle del Cinca. E-22400 Monzón, Huesca, Spain.

${ }^{6}$ BRINZAL. Albergue Juvenil Richard Schirrmann. Casa de Campo, s/n. E-28011 Madrid, Spain

${ }^{7}$ Agentes Medioambientales de la Generalitat Valenciana. Conselleria de Medio Ambiente, Agua, Urbanismo y Vivienda. Servicios Territoriales de Castellón. E-12003 Castellón, Spain.

${ }^{8}$ Empresa de Gestión Medioambiental-Consejería de Medio Ambiente, Junta de Andalucía, Recinto Interior Zona Franca Edificio Melkart, $1^{\circ}$ Planta, mod. 1-7, E-11011 Cádiz, Spain.

${ }^{9}$ Centro de Recuperación de Fauna "Forn del Vidre”. Conselleria de Medio Ambiente, Agua, Urbanismo y Vivienda. Generalitat Valenciana. Spain.

${ }^{10}$ Parque Natural del Prat de Cabanes-Torreblanca. E-12595 Ribera de Cabanes, Castellón, Spain.

* Corresponding Author: Ruben Limiñana. Instituto de Investigación en Recursos Cinegéticos (IREC-CSIC-UCLM-JCCM). Ronda de Toledo, s/n. Ciudad Real E-13005, Spain. Tel: +34 9262954 50. Fax: +34 9262954 51. E-mail: ruben.lm@gmail.com 


\section{ABSTRACT}

Natal dispersal is an important component of bird's ecology, plays a key role in many ecological and evolutionary processes, and has important conservation implications. Nevertheless, detailed knowledge on natal dispersal is still lacking in many bird species, especially raptors. We review and compile existing information from five tagging programmes of juvenile Montagu's harriers (Circus pygargus) in different Spanish regions, with PVC rings or wing-tags, to provide an assessment of philopatry and natal dispersal of the species in Spain. Only 7\% of all tagged harriers were observed as breeders in subsequent years. The percentage of philopatric (i.e. breeding within $10 \mathrm{~km}$ of natal site) males and females was lower that $5 \%$. There were no sexual differences in percentage of philopatric birds or dispersal distances, but we found study-area differences. The low philopatry observed suggests a high capacity for natal dispersal in this species, for both sexes, and therefore high genetic mixing between populations. Differences in philopatry between study areas may be influenced by the different observation effort or detectability, or else reflect different philopatric strategies among populations. Finally, we found no significant differences in philopatry rate or dispersal distances related to tagging method, suggesting that tagging technique has a smaller effect than monitoring effort or observation ease on observation probability. Developing tagging programmes at a small scale and without procuring very large-scale and intensive subsequent monitoring is not worthwhile for evaluating philopatry and natal dispersal in this species.

Keywords: conservation; juvenile dispersal; raptors; tagging methods. 


\section{INTRODUCTION}

Natal dispersal (hereafter dispersal) can be defined as the movements of juveniles from the parental territory to the place of their first reproductive attempt (Greenwood and Harvey 1982). This stage of the life cycle plays a key role in many aspects of the ecology and demography of species, and is therefore tightly linked to their persistence and conservation (Clobert et al. 2001; Gadgil 1971; Johnson and Gaines 1990). In particular, dispersal distances (i.e., distance between natal and first reproductive attempt sites) are probably linked to the level of genetic mixing between populations, since dispersal is a mechanism for linking populations (Bullock et al. 2002; Clobert et al. 2001) and therefore, its knowledge is fundamental to understand many ecological and evolutionary processes, as well as to design successful conservation strategies (e.g. Paradis et al. 1998). Genetics and demography of highly philopatric species, where most birds return to breed close to their natal territories, may contrast strongly with those where a proportion of juveniles settle in other areas (e.g. Avise 2000; Clobert et al. 2001). Nevertheless, detailed knowledge on dispersal is still lacking in many bird species, especially raptors, given the inherent difficulties to work with them (Penteriani and Delgado 2009; but see e.g. Cadahía et al. 2010; Delgado et al. 2010).

Sexual differences in dispersal patterns within a species or population may be also important to reduce the degree of inbreeding. In birds, the dispersive sex is usually females, whereas males tend to be more philopatric (see Greenwood 1980 for a review). This is also common in several raptor species (e.g. Cadahía et al. 2009, 2010; Forero et al. 2002; Hernández-Matías et al. 2010; Serrano et al. 2003). In many raptor species, males select the breeding area and provide most food for female and nestlings; in this sense, returning to a familiar site may have benefits for males in terms of assuring a good breeding site (Greenwood 1980). However, these sexual differences in dispersal distances have not been found in other bird species, including also raptors (e.g. Negro et al. 1997).

The Montagu's harrier (Circus pygargus) is a migratory raptor with breeding grounds in Europe and Asia and wintering areas in Africa and India (Cramp and Simmons 1980). France and the Iberian Peninsula represent the stronghold of Western European breeding populations, where the species generally breeds in agricultural areas, mostly 
cereal crops (Arroyo et al. 2004). In this species, males usually arrive first to the breeding grounds and select the nesting place (Arroyo 1995), also providing the female with food during most of the breeding season. The species is relatively well studied, and there exist a large number of papers on several aspects of its ecology, from breeding biology to migration (see Arroyo et al. 2004 and references therein). However, barely any published data regarding dispersal in this species exist, although it is generally considered that the species is not highly philopatric (Arroyo et al. 2004).

Here, we review and compile existing information from various medium to long-term tagging programmes of juvenile Montagu's harriers in several Spanish regions to provide a first assessment of the degree of philopatry and dispersal of the species in Spain. Specifically, we evaluate: 1) the proportion of juveniles observed breeding close to their natal area; and 2) dispersal distances. We also assess whether these two parameters vary (a) between sexes, (b) among regions, and (c) whether they may be influenced by the tagging method used (PVC rings vs. wing-tags, see the "Tagging and dispersal data” section). We discuss both the potential for population connectivity in this species and its implications for conservation, as well as the potential impact of tagging techniques and monitoring effort in results obtained when evaluating dispersal in this species.

\section{METHODS}

\section{Tagging and dispersal data}

We used data from five juvenile harrier tagging programmes in different regions of Spain (Figure 1): (1) Madrid (central Spain), where wing-tags were used in a $200 \mathrm{~km}^{2}$ agricultural area from 1992 to 1998 (monitoring period: 1991-2000); monitoring effort was high and associated to a population research project aimed to locate all nests in the area, and to tag all fledglings in the study area every year; Arroyo 1995, 2002; Arroyo et al. 2002), (2) Extremadura (Southwestern Spain), where wing-tags where used from 2003 to 2006 (monitoring period: 2002-2008) on birds released by hacking in three different points; the monitoring area covered most of the agricultural areas in Badajoz province (ca. 25,000 $\mathrm{km}^{2}$ ), associated to nest location for conservation purposes; 
monitoring intensity was relatively low, as conservation volunteers were more concentrated on nest location than on tag reading, (3) Huesca (Northeastern Spain), where wing-tags were used in a 1,100 $\mathrm{km}^{2}$ area from 1995 to 2006 (monitoring period: 1995-2008); monitoring intensity was also relatively low, (4) Castellón (Eastern Spain) where PVC rings were used from 2002 to 2006 in a 1,200 $\mathrm{km}^{2}$ area (monitoring period: 2002 to 2008); monitoring effort was also high and associated to a population study, that aimed to locate most of the nests every year, and tag a significant proportion of nestlings (those fledged from ca. 75\% of nests of the population; Limiñana et al. 2006); however, reading of PVC rings was hindered by access to nests and perching places, and (5) Tarifa (Southern Spain), where PVC rings were used in a $50 \mathrm{~km}^{2}$ agricultural area from 2004 to 2009 (monitoring period: 2004-2010); all nests in this area were located every year and monitoring intensity was relatively high during the period 20042007, and very high and associated to a population study from 2008 to 2010.

We noted the total number of males and females tagged each study year in each region. Juvenile harriers were sexed by means of iris colour, a technique that has been proven extremely accurate in this species (Forsman 1999). In the Tarifa region, fledglings were not sexed in the first three tagging years. Sex ratio of sexed nestlings in this area during the other years was 1:1 (18 males:17 females). Thus, for the years for which harriers in this region were not sexed, we estimated the number of birds of each sex tagged in a given year as half the total number of fledglings tagged in this year. Overall, a total of 1662 juvenile harriers were tagged in these programmes during the study periods mentioned above (Table 1). Observations of these tagged birds in subsequent years were achieved during monitoring activities of the different populations. Outside these study areas, tag readings were provided by ornithologists or by people working in Montagu's harrier conservation programmes (and thus looking for nests) in different areas than study sites. We considered birds as "breeders" when they were seen involved in breeding activities (males transferring food to females, entering nests, etc. Arroyo and García 2007); additionally, we also included observations of tagged harriers if they were repeated and well within the breeding period (May-June), even if no proof of breeding had been provided (this happened mostly for observations in Extremadura, where monitoring was not intensive, and also for some of those outside the study areas, provided by occasional observers, as specified above). We only used data of the first known breeding attempt for calculations (i.e., excluding observations of the same birds 
in subsequent years). For every used observation, we calculated the distance from the natal place to the breeding site ( $\pm 1 \mathrm{~km})$.

\section{Statistical analyses}

Montagu's harrier pairs have a home range during the breeding season of ca. 5-10 km around the nest (Arroyo et al. 2004; Guixé and Arroyo 2011). Additionally, pairs build their nests on the ground every year and the exact location may change up to several kilometres, considering the interannual spatial variation in habitat associated to farmland dynamics. Therefore, we considered a harrier as "philopatric" if it was found breeding for the first time within $10 \mathrm{~km}$ from its natal nest. This definition is similar to that used in other raptors (Negro et al. 1997; Forero et al. 2002) but may be also considered as a conservative estimate, as birds breeding at distances higher than $10 \mathrm{~km}$ from its natal nest may be considered as nesting within the same population. For comparison, we also calculated the proportion of birds breeding for the first time within $50 \mathrm{~km}$ from its natal nest (Table 1).

First, we calculated the percentage of "philopatric" birds for every region. Even if monitoring effort varied strongly between study areas, we consider that this figure is mostly comparable among areas, as most effort was done close to tagging sites. We analyzed the differences in these percentages among regions and between sexes, as well as for the two tagging techniques (wing-tags vs. PVC rings) using chi-square tests (Zar 1999). Secondly, we calculated the median dispersal distance for non-philopatric birds (those found breeding further away from $10 \mathrm{~km}$ from their natal place) for every region, sex and tagging method, and differences in this variable were assessed using the nonparametric Mann-Whitney (for sex and tagging method) and Kruskal-Wallis (for region) tests (Zar 1999).

\section{RESULTS}

Table 1 summarizes percentages of observed birds from those tagged in each region and also according to tagging technique, as well as median dispersal distances (for those birds found first breeding beyond $10 \mathrm{~km}$ from natal site). Overall, only 117 Montagu's 
harriers (7\% of tagged birds) were ever observed breeding in subsequent years. There was a trend for fewer observations of harriers tagged with PVC rings than with wingtags, although the percentages of observations were not significantly different $\left(\chi^{2}{ }_{1}=\right.$ 3.63, $\mathrm{p}=0.06)$.

The percentage of both females and males observed breeding within $10 \mathrm{~km}$ of the natal site was lower than 5\% (Table 1), and values observed did not vary significantly between sexes $\left(\chi_{1}^{2}=1.2, \mathrm{p}=0.2\right)$. This percentage strongly varied among sites for females, being close to $10 \%$ in the two sites with higher monitoring intensity (Madrid and Tarifa; Table 1). The percentage of "philopatric” males also varied strongly between sites, even between the two sites with highest monitoring intensity $\left(\chi_{1}^{2}=26.6\right.$, $\mathrm{p}=0.001$ ). In Tarifa, a striking $25 \%$ of tagged males were observed breeding (or attempting to breed) close to their natal territories.

For those individuals that dispersed (i.e., were found breeding for the first time further away than $10 \mathrm{~km}$ from their natal site), median dispersal distance at which they were observed was not significantly different between sexes (Kruskal-Wallis $\mathrm{H}=2.43, \mathrm{p}=$ 0.48, Table 1). However, the overall dispersal patterns (according to dispersal distances distribution) were different for males and females, and all but one of the recorded dispersal distances higher than $100 \mathrm{~km}$ corresponded to females (Fig. 2), the longest being $508 \mathrm{~km}$. In general, median dispersal distances at which harriers were observed were higher when using wing-tags than when using PVC rings (Table 1), although differences were not statistically significant (Kruskal-Wallis $\mathrm{H}=2.17, \mathrm{p}=0.14$ ). In the case of males with PVC rings, observations of breeders only occurred within $10 \mathrm{~km}$ of the natal site.

\section{DISCUSSION}

Results in this study indicate that, in general, a relatively low proportion of Montagu's harrier fledglings tagged with either PVC rings or wing-tags are observed breeding in subsequent years. Likelihood of observing tagged birds as breeders depends on a combination of factors, such as survival probability, degree of philopatry, observation likelihood and monitoring effort. The latter two factors are likely to decrease with 
distance from natal site, as most studies have a high observation effort within the limits of the study areas, but much lower outside them and hence, probability of detecting a tagged bird outside monitored areas is also lower. Additionally, observation probability is likely to depend on the tagging technique; it is generally easier to detect a wing-tag on a bird than a PVC ring on a leg (Green et al. 2004) and it is also easier to read the individual codes at a longer distance, whereas reading PVC rings is usually possible only when birds are perched relatively close from the observer. Moreover, the higher visibility of wing-tags increases the probability of viewing and reading tagged birds outside the well-monitored study areas, since these observations generally rely on occasional observers (who may be less willing to spend long periods of time to wait for a bird perching in the adequate conditions for reading a PVC ring). However, our results suggest that tagging technique seems to have a smaller effect on observation probability than monitoring intensity or observation ease. For example, in Castellón, despite the high monitoring effort, it was difficult to identify all breeding birds individually due to the combination of difficult-to-detect tags used (PVC rings) and the nature of the study area (birds nested in dense shrub and were difficult to approach at close distances, and they had several natural sites to perch, thus preventing the use of artificial perches to read PVC rings). On the contrary, it seems that in Extremadura or Huesca, despite the use of wing-tags and the open agricultural habitats, the low monitoring effort (due to the absence of a specific monitoring population programme, or the very large area covered in the case of Extremadura) may have prevented achieving more observations and hence, better results on harrier dispersal. Finally, there are several breeding areas of the species in Spain that remain ineffectively monitored (Figure 1) where birds may have been recruited to the breeding population, and this may influence the low total number of Montagu's harriers observed outside the study areas.

Despite the varying reliability of data from the different tagging programmes, our results indicate that a relatively small proportion of birds bred close (within $10 \mathrm{~km}$ ) to their natal areas. Juvenile survival rate in the species has been estimated between 31$69 \%$, and survival rate beyond the second winter has been estimated as 67-75\% (Arroyo 2009; Millon and Bretagnolle 2008). This means that, even using the less conservative estimate for philopatry (birds breeding within $50 \mathrm{~km}$ of their natal site, Table 1), only 8$19 \%$ of males and 13-33\% of females are philopatric (estimates calculated for birds surviving two years, lower values using the higher survival estimates, higher values 
using the lower survival estimates). Thus, an important proportion of birds must settle to breed outside the natal areas, showing a high capacity for dispersal in this species, for both sexes, confirming the initial suggestion for the species (Arroyo et al. 2004). The alternative would be that a high proportion of breeding tagged birds go unnoticed within study areas, but this is very unlike to happen, at least with wing-tagged birds breeding in study areas that are intensively monitored for population studies like Madrid, or in small areas with high monitoring effort like Tarifa. Hence, this result also suggests a high capacity for genetic exchange between populations, which would lead to relatively low genetic differentiation between populations of Western Europe. Such low degree of population genetic structuring has been recently described in this species (García et al. 2011).

Differences in philopatry between study areas may be influenced by the different observation effort or detectability, or else reflect different philopatric strategies among populations which may be related to breeding context (Forero et al. 2002). In other words, even if the same proportion of juveniles would be returning to their natal area in the different populations, the actual number of birds that are recruited to the breeding population may be dependent on the number of vacant sites amongst the breeding population. In this sense, a high philopatry rate may be related to a higher carrying capacity (Soutullo et al. 2006) or to a lower survival of adult birds from this population (Hernández-Matías et al. 2010). This could also apply to sexual differences in philopatry observed between study areas. Differential sex-related survival rates between populations may have a significant effect in determining the percentage of birds of each sex that are actually recruited to the breeding population in a given area. For example, it is unlikely that the differences found for the proportion of philopatric males between Madrid and Tarifa, the two sites with highest monitoring intensity, are simply due to chance or monitoring effort, which may thus suggest a lower survival rate of males in Madrid. Numbers of tagged nestlings of each sex were estimated in Tarifa, but even if we assume a 70:30 male sex ratio in the years when tagged nestlings were not sexed, the proportion of philopatric males would still be $20 \%$, much higher than the proportion observed in Madrid.

Our results also show that the method used and, more importantly, the monitoring effort and observation possibilities may have an important influence in the results achieved. 
Wing-tags seem to provide better results in detecting long dispersal distances, although they may also have detrimental effects, including higher mortality rates, in some species (Southern and Southern 1985). In the case of Montagu's harriers, wing-tags do not seem to have effects on either survival or mating probabilities (Bavoux et al. 2001), although more detailed studies are needed to evaluate this (as if detrimental effects would exist, this would influence the conclusions extracted from our results). Results presented in this study reflect a very large number of fledglings tagged (more than 1500) and medium to long-term monitoring programmes but however, even then, results are mostly inconclusive for most parameters evaluated (e.g., sexual differences in dispersal, etc). This strongly indicates that developing tagging programmes of Montagu's harrier fledglings at a small scale and without procuring very large scale and intensive subsequent monitoring is not worthwhile for evaluating philopatry and dispersal in this species. If this aspect of Montagu's harrier population ecology needs to be developed elsewhere, studies may be better focused to count on techniques other than wing-tags or PCV rings (such as genetic analyses, etc) or on working at a very large scale (as in a recent project developed in France, www.busards.com).

\section{ACKNOWLEDGEMENTS}

We are grateful to Servicio de Biodiversidad from Conselleria de Medio Ambiente, Agua, Urbanismo y Vivienda (Generalitat Valenciana), for providing data from Castellón area. In Tarifa the population study was funded by Fundación Migres through a collaboration project with the Asociación Eólica de Tarifa, and the ringing program was carried out by Milvus-GOES and Cigüeña Negra ringing groups. R. L. has a postdoctoral grant (reference 10/12-C) co-funded by Consejería de Educación y Ciencia (Junta de Comunidades de Castilla-La Mancha) and the European Social Fund. Finally, we are thankful to Vincenzo Penteriani and Chris Trierweiler for their comments on an earlier draft of the manuscript. Research conducted to obtain the data presented here comply with the current laws of Spain.

\section{REFERENCES}

Arroyo BE (1995) Breeding ecology and nest dispersion of Montagu's Harrier Circus pygargus in central Spain. PhD Thesis Dissertation, University of Oxford 
Arroyo B (2002) Fledging sex ratio variation and future reproduction probability in Montagu’s harrier, Circus pygargus. Behav Ecol Sociobiol 52:109-116

Arroyo B, García JT, Bretagnolle V (2002) Conservation of the Montagu's harrier (Circus pygargus) in agricultural areas. Anim Conserv 5:283-290

Arroyo B (2009) Ecología poblacional del aguilucho cenizo en Europa: implicaciones para su conservación. In: Conservación y situación poblacional de los aguiluchos en Eurasia. Dirección General del Medio Natural, Junta de Extremadura, Badajoz, pp 1-10

Arroyo BE, García JT (2007) El aguilucho cenizo y el aguilucho pálido en España. Población en 2006 y métodos de censo. SEO/Birdlife, Madrid

Arroyo BE, García JT, Bretagnolle V (2004) Montagu’s Harrier Circus pygargus. In: Birds of Western Palaearctic Update, Vol. 6, pp 41-55

Avise JC (2000) Phylogeography: the history and formation of species. Harvard University Press, Cambridge

Bavoux C, Burneleau G, Leroux A, Bretagnolle V (2001) Influence du marquage alaire sur les busards des roseaux et les busards cendrés. Circuslaire 2:2-3.

Bullock JM, Kenward RE, Hails RS (eds) (2002) Dispersal ecology. Blackwell, Oxford

Cadahía L, López-López P, Urios V, Soutullo A, Negro JJ (2009) Natal dispersal and recruitment of two Bonelli's Eagles Aquila fasciata: a four-year satellite tracking study. Acta Ornithol 44:193-198

Cadahía L, López-López P, Urios V, Negro JJ (2010) Satellite telemetry reveals individual variation in juvenile Bonelli’s eagle dispersal areas. Eur J Wildl Res 56:923-930

Clobert J, Danchin E, Dhont AA, Nichols J (eds) (2001) Dispersal - Causes, Consequences and Mechanisms of Dispersal at the Individual, Population and Community Level. Oxford University Press, Oxford

Cramp S, Simmons KEL (1980) The birds of the Western Palaearctic, Vol. 2. Oxford University Press, Oxford

Delgado MM, Penteriani V, Revilla E, Nams VO (2010) The effect of phenotypic traits and external cues on natal dispersal movements. J Anim Ecol 79:620-632

Forero MG, Donázar JA, Hiraldo F (2002) Causes and fitness consequences of natal dispersal in a population on black kites. Ecology 83:858-872

Forsman D (1999) The Raptors of Europe and the Middle East: A Handbook of Field Identification. T \& AD Poyser, London 
Gadgil M (1971) Dispersal: population consequences and evolution. Ecology 52:253261

García J, Alda F, Terraube J, Mougeot F, Sternalski A, Bretagnolle V, Arroyo B. 2011. The genetic effects of Holocene climatic change on steppe-associated fauna: demographic history, genetic structure and gene flow in a raptor species. BMC Evolutionary Biology 11: 333 (doi:10.1186/1471-2148-11-333)

Green AJ, Fuentes C, Vázquez M, Viedma C, Ramón N (2004) Use of wing tags and other methods to mark marbled teal (Marmaronetta angustirostris) in Spain. Ardeola 51:191-202

Greenwood PJ, Harvey PH (1982) The natal and breeding dispersal of birds. Ann Rev Ecol Syst 13:1-21

Greenwood PJ (1980) Mating systems, philopatry and dispersal in birds and mammals. Anim Behav 28:1140-1162

Guixé D, Arroyo B (2011) Appropriateness of Special Protection Areas for wideranging species: the importance of scale and protecting foraging, not just nesting habitats. Anim Conserv. doi: 10.1111/j.1469-1795.2011.00441.x

Hernández-Matías A, Real J, Pradel R, Ravayrol A, Vincent-Martin N, Bosca F, Cheylan G (2010) Determinants of territorial recruitment in Bonelli’s eagle (Aquila fasciata) populations. The Auk 127:173-184

Johnson ML, Gaines MS (1990) Evolution of dispersal: theoretical models and empirical tests using birds and mammals. Ann Rev Ecol Syst 21:449-480

Limiñana R, Surroca M, Miralles S, Urios V, Jiménez J (2006) Population trend and breeding biology of Montagu's Harrier Circus pygargus in a natural vegetation site in northeast Spain. Bird Study 53:126-131

Millon A, Bretagnolle V (2008) Predator population dynamics under a cyclic prey regime: numerical responses, demographic parameters and growth rates. Oikos $117: 1500-1510$

Negro JJ, Hiraldo F, Donázar JA (1997) Causes of natal dispersal in the lesser kestrel: inbreeding avoidance or resource competition? J Anim Ecol 66:640-648

Paradis E, Baillie SR, Sutherland WJ, Gregory RD (1998) Patterns of natal and breeding dispersal in birds. J Anim Ecol 67:518-536

Penteriani V, Delgado MM (2009) Thoughts on natal dispersal. J Raptor Res 43:90-98

Serrano D, Tella JL, Donázar JA, Pomarol M (2003) Social and individual features affecting natal dispersal in the colonial lesser kestrel. Ecology 84: 3044-3054 
Southern LK, Southern WE (1985) Some effects of wing tags on breeding Ring-billed gulls. The Auk 102:38-42

Soutullo A, Limiñana R, Urios V, Surroca M, Gill JA (2006) Density-depent regulation of population size in colonial breeders: Allee and buffer effects in the migratory Montagu’s harrier. Oecologia 149:543-552

Zar JH (1999) Biostatistical Analysis, 4th Edition. Prentice Hall, New Jersey 
Table 1. Sample sizes and dispersal parameters. This includes: Number of birds tagged; proportion of tagged birds of both sexes observed subsequently breeding (\% females and males observed), proportion of tagged birds breeding closer than $10 \mathrm{~km}$ from natal site (\% males/females observed $<10 \mathrm{~km}$ ), or closer than $50 \mathrm{~km}$ from natal site (\% males/females observed $<50 \mathrm{~km}$ ); and median dispersal distances (calculated only from birds breeding $>10 \mathrm{~km}$ from natal site). For percentages, sample size (number of birds observed) is shown in brackets. Totals per tagging technique (PVC rings and wing tags) are calculated pooling data from all sites using the same technique. The overall totals are calculated pooling data of all study areas.

\begin{tabular}{|c|c|c|c|c|c|c|c|c|c|c|c|c|c|}
\hline Site & $\begin{array}{l}\text { Tagging } \\
\text { method }\end{array}$ & $\begin{array}{l}\text { Monitoring } \\
\text { effort }\end{array}$ & $\begin{array}{l}\text { Number } \\
\text { of tagged } \\
\text { females }\end{array}$ & $\begin{array}{l}\text { Number } \\
\text { of tagged } \\
\text { males }\end{array}$ & $\begin{array}{c}\text { \% females } \\
\text { observed }\end{array}$ & $\begin{array}{l}\% \text { males } \\
\text { observed }\end{array}$ & $\begin{array}{c}\% \\
\text { observed } \\
\text { (total) }\end{array}$ & $\begin{array}{c}\% \\
\text { females } \\
\text { observed } \\
<10 \mathrm{~km}\end{array}$ & $\begin{array}{c}\% \text { males } \\
\text { observed } \\
<10 \mathrm{~km}\end{array}$ & $\begin{array}{c}\% \\
\text { females } \\
\text { observed } \\
<50 \mathrm{~km}\end{array}$ & $\begin{array}{c}\% \text { males } \\
\text { observed } \\
<50 \mathrm{~km}\end{array}$ & $\begin{array}{c}\text { Median } \\
\text { dispersal } \\
\text { distance } \\
\text { females } \\
(\mathrm{km})\end{array}$ & $\begin{array}{c}\text { Median } \\
\text { dispersal } \\
\text { distance } \\
\text { males } \\
(\mathrm{km})\end{array}$ \\
\hline Castellón & PVC & High & 406 & 357 & $3.2(13)$ & $0.6(2)$ & 2.0 (15) & $1.2(5)$ & $0.5(2)$ & $2.2(9)$ & $0.5(2)$ & 100 & $<10$ \\
\hline Madrid & WT & High & 258 & 218 & $19.8(51)$ & $7.8(17)$ & $14.3(68)$ & $9.7(25)$ & $3.7(8)$ & $18.2(47)$ & $6.2(16)$ & 63 & 36 \\
\hline Extremadura & WT & Low & 63 & 77 & $7.9(5)$ & $2.6(2)$ & $5.0(7)$ & $3.2(2)$ & $0.0(0)$ & $4.8(3)$ & $0.0(0)$ & 63 & 58 \\
\hline Huesca & WT & Low & 99 & 80 & $5.1(5)$ & $5.0(4)$ & $5.0(9)$ & $0.0(0)$ & $2.5(2)$ & $3.0(3)$ & $3.0(3)$ & 132 & 45 \\
\hline Tarifa & PVC & High & 52 & 52 & $9.6(5)$ & $25.0(13)$ & $17.3(18)$ & $9.6(5)$ & $25.0(13)$ & $9.6(5)$ & 25.0 (13) & $<10$ & $<10$ \\
\hline $\begin{array}{l}\text { TOTAL WING- } \\
\text { TAGS }\end{array}$ & & & 420 & 375 & $14.5(61)$ & $6.1(23)$ & $10.6(84)$ & $6.4(27)$ & $2.7(10)$ & $12.6(53)$ & 4.5 (19) & 15 & 15 \\
\hline $\begin{array}{l}\text { TOTAL } \\
\text { PVC RINGS }\end{array}$ & & & 457 & 409 & $3.9(18)$ & $3.8(15)$ & $3.8(33)$ & $2.2(10)$ & $3.2(15)$ & 3.1 (14) & $3.3(15)$ & 5.7 & 1.7 \\
\hline TOTAL & & & 878 & 784 & $9.0(79)$ & $4.8(38)$ & 7.0 (117) & $4.2(37)$ & $3.2(25)$ & $7.6(67)$ & $3.9(34)$ & 15 & 5 \\
\hline
\end{tabular}




\section{FIGURE CAPTIONS}

Figure 1. Location of the study areas and observations of dispersing Montagu's harriers (birds observed breeding beyond $10 \mathrm{~km}$ from their natal places). Each observation has the symbol (in smaller font) of the study area where the bird was tagged. All birds observed around Madrid study area were born in that study area. The breeding areas of the species in Spain are depicted in light grey (in 10x10 km pixels; modified from Arroyo and García 2007).

Figure 2. Frequency distribution of dispersal distances of Montagu's harriers according to sex. Only birds that bred further from $10 \mathrm{~km}$ from natal site are included (see text for details). 
Figure 1

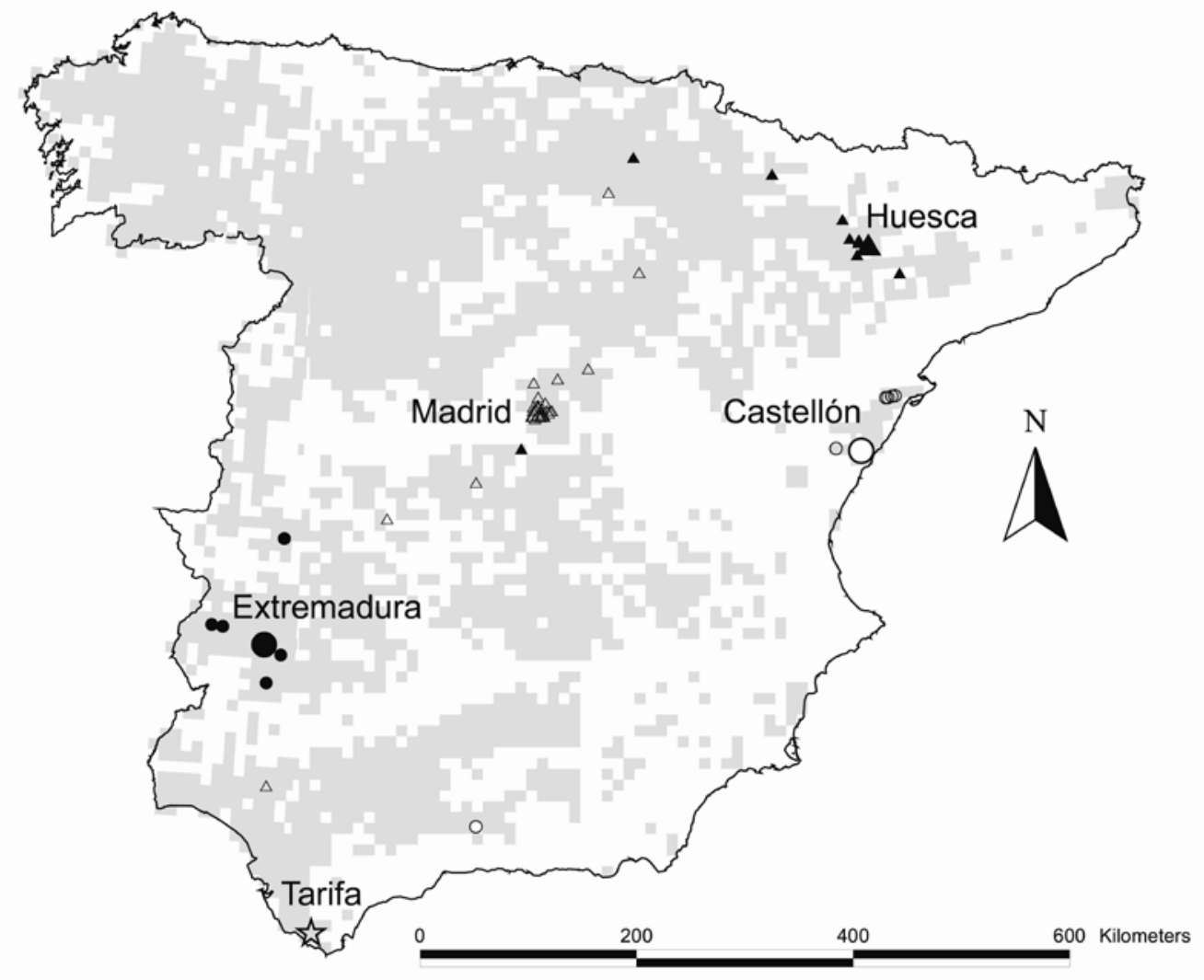


Figure 2

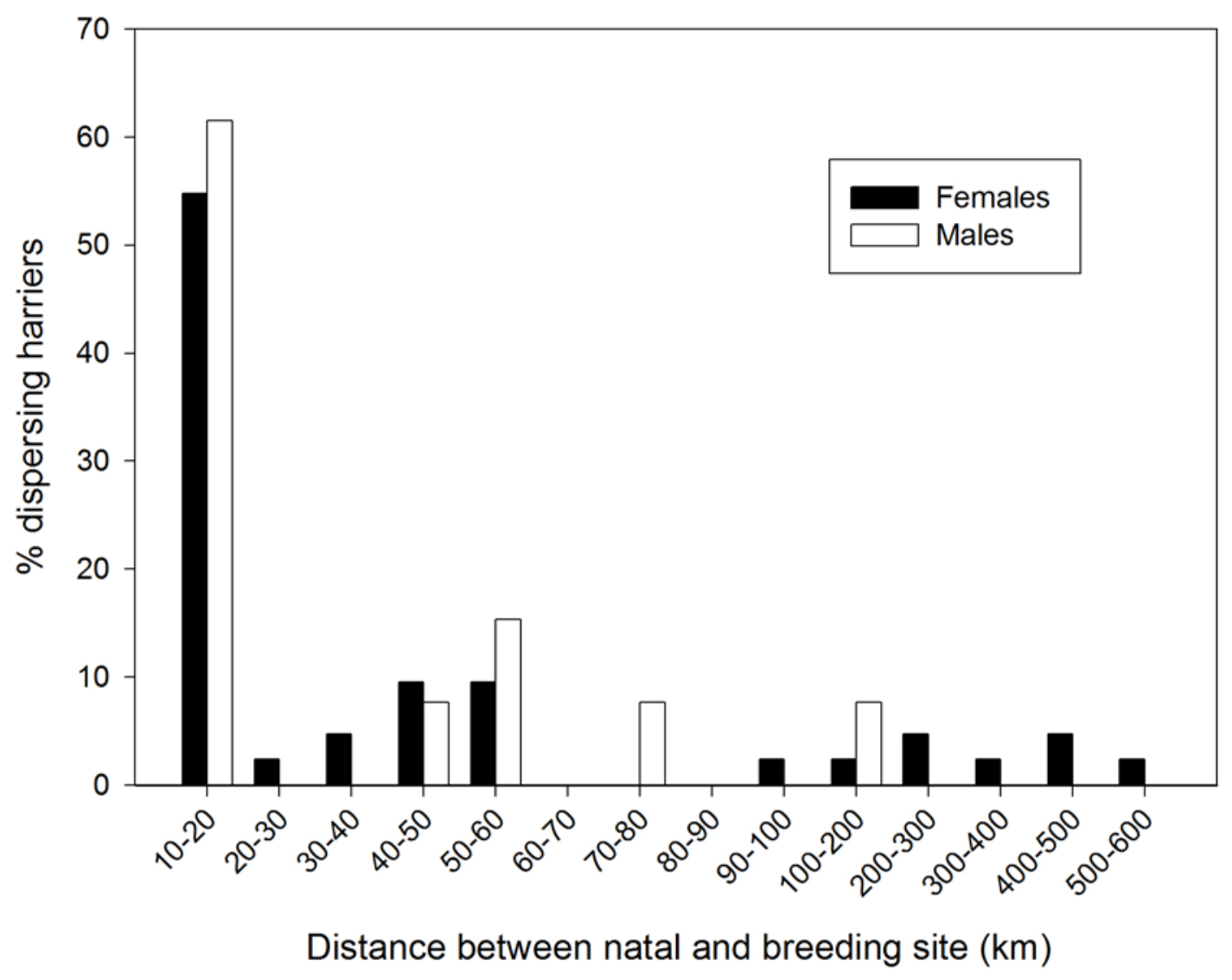

